\title{
an introduction to fensegrily
}


UNIVERSITY OF CALIFORNIA PRESS BERKELEY • LOS ANGELES • LONDON 
an introduction to

tensegrity

by Anthony Pugh 
University of California Press

Berkeley and Los Angeles, California

University of California Press, Ltd.

London, England

Copyright $(\odot) 1976$, by

The Regents of the University of California

ISBN 0-520-02996-8 (clothbound)

ISBN 0-520-03055-9 (paperbound)

Library of Congress Catalog Card Number: 75-5951

Printed in the United States of America

Design: Harlean Richardson

Layout: William H. Snyder 
To

Dr. R. Buckminster Fuller

in recognition of his generous inspiration and encouragement. 
